\title{
HOMOCYSTEINE: NEUROTOXICITY AND MECHANISMS OF INDUCED HYPEREXCITABILITY
}

\author{
Stanojlovic Olivera, Hrncic Dragan, Rasic-Markovic Aleksandra and Djuric Dragan \\ Institute of Medical Physiology "Richard Burian", School of Medicine, University of Belgrade, Belgrade, Serbia

\section{HOMOCISTEIN: NEUROTOKSIČNOST I MEHANIZMI INDUKOVANE HIPEREIKSCITABILNOSTI} \\ Stanojlović Olivera, Hrnčić Dragan, Rašić-Marković Aleksandra i Đurić Dragan \\ Institut za Medicinsku fiziologiju "Rihard Burijan", Medicinski fakultet, Univerzitet u Beogradu, Beograd, Srbija
}

Received / Primljen: 09. 02. 2011.

\begin{abstract}
Within the past four decades, investigators worldwide have established that the amino acid homocysteine (Hcy) is a potent, independent, novel and emerging risk factor for arteriosclerosis. In addition, Hcy is considered a vasotoxic and neurotoxic agent that interferes with fundamental biological processes common to all living cells. The aim of this article is to present data addressing central nervous system hyperexcitability in experimental models of homocysteine-induced seizures. These results demonstrate that acute administration of homocysteine and homocysteine-related compounds significantly affects neuronal activity, electroencephalographic (EEG) recordings and behavioural responses in adult Wistar male rats. It is suggested that hyperhomocysteinemia may generate similar effects on human brain activity. Homocysteine and D,L-homocysteine thiolactone are excitotoxic and elicit seizures through stimulation of NMDA receptors. In addition, they inhibit $\mathrm{Na}^{+} / \mathrm{K}^{+}$-ATPase activity in the cortex, hippocampus and brain stem. Nitric oxide (NO) acts as an anticonvulsant in D,L-homocysteine thiolactone-induced seizures and prevents $D, L$-homocysteine thiolactone-induced inhibition of $\mathrm{Na}^{+} / \mathrm{K}^{+}$-ATPase activity. EEG monitoring for the effects of ethanol on homocysteine-induced epilepsy support the idea that ethanol intake could represent one of the exogenous factors influencing brain excitability. Finally, it was found that homocysteine thiolactone significantly inhibits acetylcholinesterase (AChE) activity in rat brain tissue.
\end{abstract}

Keywords: homocysteine, CNS, hyperexcitability, rat
Abbreviations used:
AchE - acetylcholinesterase
BHMT - betaine-Hcy S-methyltransferase
CNS - central nervous system
EEG - electroencephalography
Hcy - homocysteine
$\mathrm{NO}$ - nitric oxide
SWDs - spike-wave discharges
tHcy - total plasma homocysteine

\section{SAŽETAK}

Četiri decenije istraživačkog rada širom sveta dovele su do ustanovljavanja semi-esencijalne sulfihidrilne aminokiseline homocisteina (Hcy) kao novog potentnog i nezavisnog faktora rizika za arteriosklerozu, kao $i$ vazotoksične $i$ neurotoksične supstance koja učestvuje u fundamentalnim biološkim procesima svojstvenim svim živim ćelijama. Cilj ovog rada je da prikaže dostupna saznanja na temu hiperekscitabilnosti centralnog nervnog sistema u eksperimentalnom modelu homocisteinom indukovene epilepsije. Rezultati pokazuju da akutna administracija homocisteina $i$ homocisteinu-srodnih supstanci značajno utiče na nervnu aktivnost, elektroencefalografske (EEG) zapise i ponašanje odraslih mužjaka soja Wistar pacova, a smatra se da hiperhomocisteinemija može imati slične efekte $i$ na aktivnost ljudskog mozga. Homocistein i D,L-homocistein tiolakton su ekscitotoksični i izazivaju epileptične napade stimulacijom NMDA receptora; oni indukuju značajnu inhibiciju aktivnosti $\mathrm{Na}^{+} / \mathrm{K}^{+}$-ATPaze u korteksu, hipokampusu i moždanom stablu. Azot monoksid (NO) deluje kao antikonvulzant u D,Lhomocistein tiolakton indukovanim epileptičnim napadima $i$ vrši prevenciju D,L-homocistein tiolakton indukovane inhibicije aktivnosti $\mathrm{Na}^{+} / \mathrm{K}^{+}$-ATPaze. EEG monitoring efekata etanola na homocisteinom indukovanu epilepsiju podržava ideju da akutni unos etanola može predstavljati jedan od faktora egzogenog uticaja na moždanu ekscitabilnost. Takođe je utvrdeno da D, Lhomocistein tiolakton u značajnom procentu inhibira aktivnost acetilholinesteraze u mozgu pacova.

Ključne reči: homocistein, CNS, hiperekscitabilnost, pacov

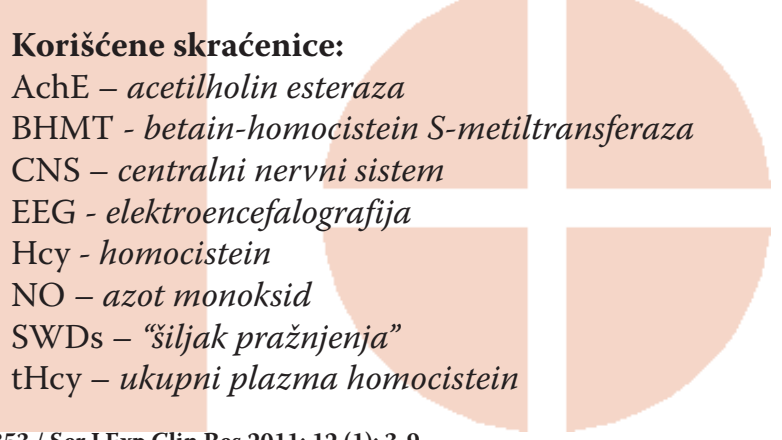

Korišćene skraćenice:

AchE - acetilholin esteraza

BHMT - betain-homocistein S-metiltransferaza

CNS - centralni nervni sistem

EEG - elektroencefalografija

Hcy - homocistein

$\mathrm{NO}$ - azot monoksid

SWDs - "siljak pražnjenja"

tHcy - ukupni plazma homocistein 


\section{BACKGROUND}

Within the past four decades, investigators worldwide have established that the amino acid homocysteine (Hcy) is a novel and independent risk factor for arteriosclerosis. In addition, Hcy is a vasotoxic and neurotoxic agent that interferes with the fundamental biological processes common to all living cells. Therefore, it has also been termed the "cholesterol of the $21^{\text {st }}$ century."

Metabolism of homocysteine is coordinately regulated to maintain a balance between remethylation and transsulfuration pathways, which are critical to maintaining low levels of this potentially cytotoxic sulphur containing amino acid (1). Homocysteine belongs to a group of molecules known as cellular thiols and is considered a "bad" thiol. Glutathione and cysteine, the most abundant cellular thiols, are considered to be "good" thiols (2). In the methylation pathway that occurs in all tissues, homocysteine acquires a methyl group to form methionine in a vitamin B12 dependent reaction, which is catalysed by methionine synthase. The second substrate required by methionine synthase is 5-methyltetrahydrofolate, which is formed by the reduction of 5,10-methylenetetrahydrofolate. This reaction is catalysed by the enzyme methylenetetrahydrofolate reductase (MTHFR). The TT genotype of this enzyme causes thermolability and reduces enzyme activity, which impairs the formation of 5-methyltetrahydrofolate. This reduced enzyme activity explains why this genotype is associated with increased Hcy levels when the folate status is relatively low. However, liver, kidney and the lens of the eye have the ability to convert Hcy to L-methionine through a vitamin $\mathrm{B} 12$-independent reaction catalysed by betaineHcy S-methyltransferase (BHMT). The CNS lacks BHMT and it is completely dependent on the folate and vitamin B12 pathway for the conversion of Hcy to L-methionine.

Homocysteine condenses with serine to form cystathionine in an irreversible reaction catalysed by the B6 containing enzyme cystathionine beta-synthase, which is known as the transsulfuration pathway. Hcy catabolism requires vitamin $\mathrm{B} 6$ and as a consequence, alterations in folic acid and B vitamin status impairs Hcy biotransformation. These alterations result in the synthesis of cysteine, taurine and inorganic sulphates that are excreted in urine.

Elevation of homocysteine levels is known to lead to the metabolic conversion and inadvertent elevation of homocysteine thiolactone, which is a reactive thioester representing less than $1 \%$ of total plasma homocysteine. In all cell types, from bacteria to human, homocysteine is metabolised to homocysteine thiolactone by methionyl-tRNA synthetase (3). Homocysteine thiolactone causes lethality, growth retardation, blisters and abnormalities in somite development by oxidative stress, which is one of important mechanisms for its toxicity to neuronal cells (4). The highly reactive and toxic homocysteine metabolite, homocysteine thiolactone, can be produced in two steps by enzymatic and/or non-enzymatic reactions in blood serum. The ability to detoxify or eliminate homocysteine thiolactone is essential for biological integrity $(3,4)$.
Total plasma Hcy (tHcy) consists of a pool of free homocysteine, homocystine, Hcy-S-S-Cys disulphide, protein bound $\mathrm{N}$ - and S-linked Hcy as well as their oxidised forms and Hcy-thiolactone (5-7). Under physiological conditions, less than $1 \%$ of the total Hcy is present in a free reduced form. Approximately $10-20 \%$ of total Hcy is present in different oxidised forms, such as Hcy-Cys and homocystine, which is a Hcy dimer. Plasma tHcy levels are affected by genetic, physiologic (age and sex) and lifestyle factors as well as various pathologic conditions $(5,6,8)$. Hyperhomocysteinemia is defined as an elevated plasma total homocysteine (tHcy) concentration $(>15 \mu \mathrm{M})$.

Elevated tHcy is a recognised risk factor for cardiovascular disease (9) and has been linked to neurological diseases during aging, such as cognitive declines, cerebrovascular disease and stroke, vascular dementia and Alzheimer's disease. In addition, elevated tHcy levels are linked with pathological brain functioning, such as mental retardation, depression, schizophrenia and memory impairment. Hcy is also a pro-thrombotic and pro-inflammatory factor, vasodilatation impairing substance and an endoplasmatic reticulum stress inducer $(10,11)$.

Mitrovic et al. (12) evaluated total plasma homocysteine in patients with angiographically confirmed coronary artery disease. In addition, they investigated the effects of homocysteine lowering therapy on endothelial function, carotid wall thickness and myocardial perfusion. Their study found that homocysteine levels decreased significantly (34\%) with folic acid therapy and that endothelium function improved by $27 \%$ with this treatment. However, carotid structure and myocardial perfusion did not show any significant improvement in patients with confirmed coronary artery disease $(13)$. Djuric et al. $(14,15)$ also investigated the link between homocysteine and folic acid, demonstrated folic acid induced coronary vasodilation and decreased oxidative stress in the isolated rat heart.

\section{HOMOCYSTEINE AND NEUROTOXICITY}

Despite several theories, a complete understanding of Hcy toxicity remains unclear. In particular, the hypothesis that relates homocysteine to CNS dysfunction by way of overt neurotoxicity is based on the neuroactive properties of homocysteine. Elucidating the link between homocysteine and CNS dysfunction is vital for improving the treatment of homocysteine related CNS disorders. Hcy adversely affects brain functioning (i.e., mental retardation, dementia and memory impairment) and high tissue concentrations cause oxidative stress and excitotoxicity in neurons (16). When these symptoms are combined with homocystinuria, patients often present with convulsions (17). These studies provide evidence for a complex and multifaced relationship between homocysteinemia and CNS disorders. Hcy is an endogenous compound that is neurotoxic at supraphysiological concentrations and induces neuronal damage and cell loss through excitotoxicity and apoptosis. These CNS 
pathologies could be a direct consequence of the inability of cerebral tissue to metabolise Hcy through the betaine and transsulfuration pathways, thereby favouring Hcy accumulation in the nervous system (18). High brain concentrations of either Hcy or its oxidised derivatives have been shown to alter neurotransmission (19). The accumulation of homocysteine (at synapses or in the extracellular space) increases intracellular S-adenosylhomocysteine (SAH), which is a potent inhibitor of many methylation reactions that are vital for neurological function including the Omethylation of biogenic amines. Methylation of myelin basic protein and reducing the synthesis of phosphatidyl choline, which can lead to blood-brain barrier (BBB) disruption, are a few pathological processes that are possible in the absence of normal methylation patterns (20).

It has been recently suggested that Hcy toxicity is a consequence of its covalent binding to proteins, which interferes with protein biosynthesis and decreases the normal physiological activity of proteins. This modification of protein function is a process called homocysteinylation. Transthyretin is a plasma protein that is modified through homocysteinylation $(3,21)$. Other reports suggest that Hcy exerts its toxicity through the induction of endoplasmic reticulum (ER) stress. Increased intracellular Hcy concentrations are associated with both the alteration of redox balance and post-translational protein modifications through $\mathrm{N}$ - and S-homocysteinylation (22). Other studies suggest that Hcy induces the expression of superoxide dismutase in endothelial cells, which leads to the consumption of NO and impairs endothelial vasorelaxation (23).

\section{HOMOCYSTEINE AND SEIZURES}

Experimental models of generalised clonic-tonic seizures induced by metaphit (1-[1(3-isothiocyanatophenyl)cyclohexyl] piperidine) $(24,25)$ and lindane $(\gamma-1,2,3,4,5,6$ hexachlorocyclohexane) $(26,27)$ are widely used for the study of epilepsy and the preclinical evaluation of potential antiepileptic treatments. In contrast to audiogenic epilepsy induced by metaphit with its typical and characteristic three degrees of intensity, the lindane model is similar to Hcy-induced epilepsy with a wide spectra of behavioural manifestations (e.g., hot plate reaction and Kangaroo position) incorporated into the rating scale from grades $0-4$. Almost four decades ago, Sprince et al. (28) described that elevated levels of homocysteine arising from excess dietary methionine may induce epilepsy and lethality. The fact that increased homocysteine concentrations damage endothelial structures and the blood coagulation system during aging and in patients on antiepileptic drugs (29) justifies the attention directed toward the examination of homocysteine's neural effects.

Furthermore, experimental models of epilepsy may be induced by manipulations of $\gamma$-aminobuturic acid (e.g., bicuculline, corasol, picrotoxin and benzylpenicillin sodium) (30). In contrast, epilepsy can be induced by an opposite mechanism such as by increasing cerebral excitatory neurotransmission. There are several proposed mechanisms by which exposure to excess D,L-homocysteine or D,L-homocysteine thiolactone induce seizures. The most reactive natural amino acid is homocysteic monocarboxylic, which is sulphur-containing and its homocysteic sulphinic acid derivatives are excitatory amino acids that have been proposed as candidates for brain excitatory neurotransmitters (31). However, answering the question as to whether D,Lhomocysteine thiolactone should be included in the list of epileptogenic factors according to behavioural and electrographic responses will require additional studies and future human therapeutic trials. Increased levels of Hcy and its oxidised forms can provoke seizures by increasing activation of certain neuronal receptors such as $\mathrm{N}$-methyl d-aspartate (NMDA), $\alpha$-amino-3-hydroxy-5-methyl-4isoxazolepropionate (AMPA)/kainate ionotropic glutamate receptors or group I and group III metabotropic glutamate receptors (5). All of these glutamate receptors are expressed in hippocampal pyramidal cells and may directly induce or drive these cells over the threshold for excitotoxic cell death. Overstimulation of these receptors triggers cytoplasmic calcium pulses, $\mathrm{Ca} 2^{+}$influx and intraneuronal calcium mobilisation in the presence of glycine (32). Increased cytosolic $\mathrm{Ca}_{2}{ }^{+}$concentrations affect enzyme activities and the synthesis of nitric oxide, which is a retrograde messenger that overstimulates excitatory amino acid receptors including glutamate, thereby lowering the convulsive threshold (33). However, expression of the NMDA receptor is not confined to neurons. Other cell types, including endothelial cells from cerebral tissue, can express this receptor. Free radicals induce the up-regulation of the NR1 subunit of the NMDA receptor, thereby increasing the susceptibility of cerebral endothelial cells to excitatory amino acids, which can lead to blood brain barrier disruption (34). Microglia are also subject to the toxic effects of Hcy (35). Hcy can induce convulsions in adults and in immature experimental animals through modulating the activity of metabotropic glutamate receptors (mGluRs) (36). Kubova et al. (37) stated that the main epileptic phenomenon in homocysteine thiolactone treated rats was emprosthotonic, flexion seizures, which are observed in young animals but never seen in rats older than 25 days. Homocysteine was shown to elicit minor (predominantly clonic) and major (generalised tonic-clonic) seizures during ontogenesis in immature Wistar rats $(36,37)$. It seems that Hcy exerts a direct excitatory effect comparable to the action of glutamate (17). In addition, Hcy has been shown to enhance either the release or uptake of other endogenous excitatory amino acids (36).

Classical anticonvulsants such as phenytoin, carbamazepine and valproic acid lower plasma folate levels and significantly increase homocysteine levels, which induces epileptogenesis and reduces the control of seizures in patients with epilepsy (38). On the other hand, increasing excitability with this native amino acid further contributes to epileptogenesis and disturbs the balance between excitation and inhibition in 
the brain. Following the work of Djuric's study, Stanojlovic et al. administered homocysteine (i.p.) to adult rats, and for the first time, convulsive and non-convulsive seizures were recorded (39). This form of epilepsy was followed by two-wave patterns of seizures with one replacing the other. It has been suggested that D,L-homocysteine thiolactone may be considered as an excitatory metabolite, which is capable of becoming a natural convulsant if accumulated to a great extent in the brain (39). Hyperhomocysteinemia in awake adult male Wistar rats induced a generalised seizure disorder characterised by recurrent unprovoked clonic-tonic convulsions and absence-like seizures as well as epileptic electrical discharges. In addition to a prolonged median latency to the first seizure, the seizure incidence, median seizure episode severity and median number of seizure episodes per rat were significantly higher in all Hcy treated groups (39). Non-convulsive status epilepticus can occur from a variety of causes, including primarily generalised absence epilepsy, genetic origins (Wakayama or tremor epileptic rats) or pharmacologically (penicillin, pentylenetetrazole or $\gamma$-hydroxy-butyric acid) induced models (40). Behavioural immobility during motor cortex activation and the occurrence of generalised spike-wave activity are among the most puzzling phenomena in absence epilepsy. According to one of numerous hypotheses addressing the development of spike-wave discharges (SWDs), these electrographic discharges may belong to the same class of phenomena such as sleep spindles. Sleep spindals are normally generated sleep rhythms that transformation one, two or more spindle waves into the spike component of the SWD (41). Cortico-thalamo-cortical oscillatory network connections may play a pacemaker role in the electrogenesis of oscillations and primarily represent the neurophysiological basis underling the initiation and propagation of SWD (40).

In keeping with the well-known fact that rhythmic bursts of spikes represent an electrophysiological marker of a hyperexcitability, Folbergrova et al. (42) found a very poor electroclinical correlation between electroencephalographic (EEG) patterns and motor phenomena in immature rats. The epileptogenic process is closely associated with the changes in neuronal synchronisation, and non-convulsive, generalised epilepsy is characterised by brief episodes of unpredictable and unresponsive behaviours with a sudden arrest accompanied by SWDs. However, the spike-wave complexes of SWDs have a unique shape. Bilateral, high-voltage, synchronous, spindle-like electrical oscillations, which are common phenomenon during paroxysmal EEG attacks, are termed SWDs. These are associated with sudden motor immobility and minor clinical signs, such as the loss of responsiveness with rhythmic twitches of vibrissae or cervicofacial musculature and are seen after i.p. administration of D,L-homocysteine thiolactone in adult rats. Interestingly, absence-like animals showed no reaction to these different stimuli (e.g., audiogenic, tactile).

Stanojlović et al. (39) found poor electro-clinical correlations in Hcy treated rats. It is worth mentioning that electrographic seizure discharges were absent even during motor convulsions of grade 3 or 4 . On the contrary, EEG seizures without motor symptoms were regularly observed. These aforementioned EEG signatures were distinguishable from sleep spindles $(10-16 \mathrm{~Hz})$ in regard to their frequency, duration, morphology (sleep spindles are more stereotyped than SWD waves) and moment of occurrence. For example, SWDs occur during passive wakefulness, while sleep spindle-like oscillations occur during high amplitude delta activity (43). The poor prognosis for the Hcy group of animals appears to be a result of the combined systemic damage caused by continuous seizure activity as well as the excitotoxic and neurotoxic effects of homocysteine accompanied by the action of free radicals, including oxidative brain damage $(42,44)$. In most of the related studies, it is not quite clear whether the observed effects are due to homocysteine itself or to homocysteine metabolites. Notably, all of the above mentioned mechanisms induce cell death (45) and result in a high mortality rate (100\%).

The basic function of the $\mathrm{Na}^{+} / \mathrm{K}^{+}$-ATPase is to maintain the high $\mathrm{Na}^{+}$and $\mathrm{K}^{+}$gradients across the plasma membrane of animal cells and it is essential for the generation of the membrane potential and maintenance of neuronal excitability (2). In addition, it has been demonstrated that there is a moderate inhibition of rat hippocampal $\mathrm{Na}^{+} / \mathrm{K}^{+}$-ATPase activity by D,L-homocysteine, which is not observed in the cortex and brain stem (46). In contrast, D,L-homocysteine thiolactone strongly inhibits $\mathrm{Na}^{+} / \mathrm{K}^{+}$-ATPase activity in cortex, hippocampus and the brain stem of rats, thereby affecting the membrane potential with deleterious effects for neurons. Considering that hyperhomocysteinemia increases formation of superoxide and hydrogen peroxide and that excitotoxicity indirectly provokes increased intracellular free radicals production, it is feasible that oxidative stress may also be associated with the CNS injury caused by homocysteine and D,L-homocysteine thiolactone (47).

Otherwise, nitric oxide (NO) is a highly reactive second messenger molecule synthesised in a number of tissues. It serves a key role in interneuronal communications via modulating release of classical neurotransmitters and influencing the excitability status of neurons (33). It is produced from L-arginine by the action of a family of enzymes known as NO synthases (NOS). Neural (nNOS) and endothelial NOS (eNOS) are $\mathrm{Ca}^{2+} /$ calmodulin-dependent enzymes, while inducible NOS (iNOS) shows $\mathrm{Ca}^{2+}$ independent properties. N-nitro-L-arginine methyl ester (L-NAME) is a non-selective NOS inhibitor commonly used to decrease NO levels. Recently, it has been determined that NO serves a role in the mechanisms underlying D,L homocysteine thiolactone induced seizures. This was demonstrated by testing the action of L- arginine (NO precursor) and L-NAME (NOS inhibitor) on behavioural and EEG manifestations of D,L homocysteine thiolactone induced seizures (48). Following Djuric's study, Hrncic et al. (48) showed functional involvement of NO in the convulsive activity of D,L-homocysteine thiolactone induced seizures in adult rats. Pretreatment with L-NAME in a dose-dependent manner increased seizure incidence and severity and shortened latency time to the first seizure following injection with a subthreshold dose of D,L-homo- 
cysteine thiolactone $(5.5 \mathrm{mmol} / \mathrm{kg}$, i.p.). Nitro indazole is an inhibitor of neuronal nitric oxide synthase that attenuates pilocarpine-induced seizures (49). NO has been shown to modulate NMDA receptor activity by interacting with the -SH group of its redox modulatory site via S-nitrosylation. This modification results in the downregulation of this receptor complex (19) and prevents the neurotoxic effects of an excessive $\mathrm{Ca}^{2+}$ influx during homocysteine induced overstimulation of NMDA and mGluRs I receptors. In addition, Kim et al. (50) demonstrated that NO ameliorates homocysteine's adverse effects of S-nitrosylation in cultured rat cortical neurons. Moreover, NO induces a reduction of glutamate by activation of glial cells. Many experimental studies have demonstrated co-localisation of NOS and GABA and have suggested that basal NO levels induce a depression of inhibition, while high concentrations of NO increase GABA release. In contrast to homocysteine, which increases oxidative stress by the production of reactive oxygen species, NO can act as a neural protector. This neuroprotective property is due to the formation of S-nitroso-L-glutathione, which is an antioxidant and NO scavenging molecule (51). However, the role of NO in epileptogenesis has been studied in different experimental models and reported results are highly contradictory. Namely, the proconvulsive role of NO has been demonstrated in the lindane model of convulsions and several others (52). Thus, it seems that the activity of NO depends on the animal strain, the seizure model employed and the type and dose of drugs used in order to modify cerebral NO levels.

Furthermore, it has been demonstrated that when Larginine is applied alone, it significantly increases the activity of $\mathrm{Na}^{+} / \mathrm{K}^{+}$-ATPase activity in the hippocampus, the cortex and the brain stem. However, when L-arginine is applied prior to D,L homocysteine thiolactone $(8 \mathrm{mmol} / \mathrm{kg})$, this completely reverses its inhibitory effect (48). The same holds true for its effects on $\mathrm{Mg}^{2+}$-ATPase activity in the rat cortex and the brain stem. L-NAME increases $\mathrm{Na}^{+} / \mathrm{K}^{+}$-ATPase activity in the cortex and the brain stem but not in the hippocampus. When L-NAME was administered prior to homocysteine thiolactone $(5.5 \mathrm{mmol} / \mathrm{kg})$, it increased the activity of both $\mathrm{Na}^{+} / \mathrm{K}^{+}$-ATPase and $\mathrm{Mg}^{2+}$-ATPase in the rat cortex and the hippocampus.

Changes in total spectral power density after ethanol alone and together with D,L-homocysteine thiolactone in adult rats were examined (53). Recording electrical activity from the brain represents a measure of both brain function and dysfunction. Ethanol is used as a social substance and is the second most widely used psychoactive substance in the world after caffeine. The influence of ethanol on the central nervous system depends on the dose, drinking pattern, tolerance and other factors. While chronic ethanol consumption is followed by a series of seizures during the withdrawal period, acute ethanol intake exerts mainly inhibitory effects on the CNS and is usually associated with an increase of seizure threshold (54). Rasic-Markovic et al. (53) found that ethanol's action on electrographic pattern is biphasic, which is char- acterised by potentiation of epileptiform activity in one dose range and depression in another one. Low ethanol doses causing euphoria and behavioural arousal are associated with desynchronisation of the EEG, decreases in the mean amplitude and increases in theta and alpha activity. In addition, ethanol increases mean total spectral power density $15 \mathrm{~min}$ and 30 min after administration. Ethanol affects voltage-gated ion channels, second messenger systems and a variety of different neurotransmitter systems such as glycine, acetylcholine as well as monoamines and neuropeptides systems (55). Two major amino acid neurotransmitter systems, GABA and glutamate, as well as aspartate are affected by ethanol. Acute administration of ethanol inhibits NMDA-induced Ca2+ influx, cyclic GMP production, neurotransmitter release and reduces NMDA-evoked neurotoxicity $(56,57)$.

Pre-treatment with MK-801, which is a NMDA receptor antagonist, showed a tendency to reduced the incidence of convulsions, latency to the first seizure onset and the severity of seizure episodes; however, there was no statistical significance when compared to the D,L-homocysteine thiolactone treated group. Nevertheless, the median number of seizure episodes was significantly decreased by MK801 when compared to the D,L-homocysteine thiolactone treated group. On the other hand, ifenprodil, which is another type of NMDA receptor antagonist, decreased the latency to the first seizure onset and increased the median number of seizure episodes. The majority of seizure episodes in the ifenprodil (72.1\%) and MK-801 (73.1\%) groups were significantly different compared to the D,L-homocysteine thiolactone treated group (36.0\%). Our findings suggest that D,L-homocysteine thiolactone induces seizures through the stimulation of NMDA receptors in the central nervous system but other mechanisms (i.e., NO signalling) may also be involved (58).

Finally, limited data exist in the literature regarding the effects of homocysteine and D,L-homocysteine thiolactone on the activity of the acetylcholinesterase (AChE) enzyme in the blood, but practically no data exist regarding the influence of these compounds on this enzyme in the brain and heart. Recent results showed a significant reduction in AChE activity in all tissues obtained from rats treated with D,L-homocysteine thiolactone compared to the enzyme activity of the control group. In addition, these results also showed that the blood enzyme activity was the lowest (12\%) after treatment, while the enzyme activity was slightly higher in the brain (27.8\%) and heart samples (86.3\%). Therefore, it was concluded that D,L-homocysteine thiolactone significantly inhibited AChE activity in the heart and brain tissue but not in the blood of the rat (59).

Overall, these studies clearly demonstrate that acute administration of homocysteine and especially D,L-homocysteine thiolactone elicit seizures in adult rats, affect neuronal activity, EEG recordings and behavioural responses. These effects have been linked to the stimulation of NMDA receptors, inhibition of the $\mathrm{Na}^{+} / \mathrm{K}^{+}$-ATPase, inhibition of AChE activity and the functional involvement of NO during D,L-homocysteine thiolactone induced seizures in adult rats. 


\section{ACKNOWLEDGEMENTS}

This work was supported by the Ministry for Science and Technological Development of Serbia, Grant No. 175032 and Grant No. 175043.

\section{REFERENCES}

1. Miller JW, Nadeau MR, Smith D, Selhub J. Vitamin B-6 deficiency vs. folate deficiency: comparison of responses to methionine loading in rats. Am J Clin Nutr 1994; 59: 1033-39.

2. Mato JM, Lu SC. Homocysteine, the bad thiol. Hepatology 2005; 41: 976-79.

3. Chwatko G, Jakubowski H. The determination of homocysteine thiolactone in human plasma. Anal Biochem 2005; 15: 271-7.

4. Obeid R, Herrmann W. Mechanisms of homocysteine neurotoxicity in neurodegenerative diseases with special reference to dementia. FEBS Lett 2006; 580: 2994-05.

5. Jakubowski $\mathrm{H}$. Homocysteine is a protein amino acid in humans.Implications for homocysteine-linked disease. J Biol Chem 2002; 277: 30425-28.

6. Jakubowski $\mathrm{H}$. The pathophysiological hypothesis of homocysteine thiolactone-mediated vascular disease. J Physiol Pharmacol 2008; 59: 155-67.

7. Syardal A, Refsum H, Ueland PM. Determination of in vivo protein binding of homocysteine and its relation to free homocysteine in the liver and other tissues of the rat. J Biol Chem 1986; 261: 3156-63.

8. De Bree A, Verschuren WMM, Kromhout D, Kluijtmans LAJ, Blom HJ. Homocysteine determinants and the evidence to what extent homocysteine determines the risk of coronary heart disease. Pharmacol Rev 2002; 54: 599-18.

9. Clarke R, Daly L, Robinson K, et al. Hyperhomocysteinemia: an independent risk factor for vascular disease. N Engl J Med 1991; 324: 1149- 55.

10. Troen AM. The central nervous system in animal models of hyperhomocysteinemia. Prog Neuropsychopharm Biol Psych 2005; 29: 1140-51.

11. Zou CG, Banerjee R. Homocysteine and redox signaling. Antioxid Redox Signal 2005; 7: 547-559.

12. Mitrovic V, Djuric D, Petkovic D, Hamm C. Evaluation of plasma total homocysteine in patients with angiographically confirmed coronary atherosclerosis: possible impact on therapy and prognosis. Perfusion 2002; 15: 10-19.

13. Rieth A, Dill T, Deetjen A, Djuric D, Mitrovic V. Effects of homocysteine-lowering therapy on endothelial function, carotid wall thickness and myocardial perfusion. Acta Facultatis Medicae Naissensis 2006; 23: 179-184.

14. Djuric D, Vusanovic A, Jakovljevic V. The effects of folic acid and nitric oxide synthase inhibition on coronary flow and oxidative stress markers in isolated rat heart. Molecular and Cellular Biochemistry 2007; 300(1-2): 177-183.
15. Djuric D, Jakovljevic V, Rasic-Markovic A, Djuric A, Stanojlovic O. Homocysteine, folic acid and coronary artery disease: possible impact on prognosis and therapy. Indian J Chest Dis Allied Sci 2008; 50: 39-48.

16. Reis EA, Zugno AI, Zugno AI, et al. Pretreatment with vitamins $E$ and $C$ prevents the impairment of memory caused by homocysteine administration in rats. Metab Brain Disease 2002; 17: 211-17.

17. Wuerthele SE, Yasuda RP, Freed WJ, Hoffer BJ. The effect of local application of homocysteine on neuronal activity in the central nervous system of the rat. Life Sci 1982; 31: 2683-91.

18. Finkelstein JD. The metabolism of homocysteine: pathways and regulation. Eur J Pediatr 1998; 157: S40-Z44

19. Lipton SA, Rosenberg PA. Excitatory amino acids as a final common pathway for neurological disorders. $\mathrm{N}$ Engl J Med 1994; 330: 613- 22.

20. Kamath AF, Chauhan AK, Kisucka J, et al. Elevated levels of homocysteine compromise blood-brain barrier integrity in mice. Blood 2006; 107: 591-93.

21. Hanyu N, Shimizu T, Yamauchi K, Okumura N, Hidaka H. Characterization of cysteine and homocysteine bound to human serum transthyretin. Clin Chim Acta 2009; 403: 70-75.

22. Chigurupati S, Wei Z, Belal C, et al. The homocysteineinducible endoplasmic reticulum stress protein counteracts calcium store depletion and induction of CCAAT enhancer-binding protein homologous protein in a neurotoxin model of Parkinson disease. J Biol Chem 2009; 284: 18323-33.

23. Hucks D, Thuraisingham RC, Raftery MJ, Yagoob MM. Homocysteine induced impairement of nitric oxide-dependent vasorelaxation is reversible by the superoxide dismutase mimetic TEMPOL. Nephrol Dial Transpl 2004; 19: 1999-05.

24. Stanojlovic O, Zivanovic D, Susic V. N-methyl-D-aspartic acid and metaphit-induced audiogenic seizures in rat model of seizure. Pharmacol Res 2000 42: 247-53.

25. Stanojlovic O, Hrncic D, Racic A, Loncar-Stevanovic $\mathrm{H}$, Djuric D, Susis V. Interaction of delta sleep-inducing peptide and valproate on metaphit audiogenic seizure model in rats. Cell Mol Neurobiol 2007; 27: 923- 32.

26. Vucevic D, Hrncic D, Radosavljevic T, et al. Correlation between electroencephalographic and motor phenomena in lindane - induced experimental epilepsy in rats. Canad J Physiol Pharmacol 2008; 286: 173-179

27. Mladenovic D, Hrncic D, Vucevic D, et al. Ethanol suppressed seizures in lindane-treated rats. Electroencephalographic and behavioral studies. J Physiol Pharmacol 2007; 58:641-54.

28. Sprince H, Parker CM, Josephs JA. Homocysteine-induced convulsions in the rat: Protection by homoserine, serine, betaine, glycine and glucose. Agents Actions 1969; 1: 9-13.

29. Perla-Kajan J, Twardowski T, Jakubowski H. Mechanisms of homocysteine toxicity in humans. Amino Acids 2007; 32:561-72. 
30. Shandra AA, Godlevskii LS, Brusentsov AI, Karlyuga VA. Effect of delta-sleep- inducing peptide on NMDAinduced convulsive activity in rats. Neurosci Behav Physiol 1998; 28: 694-97.

31. Thompson GA, Kilpatrick IC. The neurotransmitter candidature of sulphur-containing excitatory amino acids in the mammalian central nervous system. Pharmacol Ther 1996; 72: 25- 36.

32. Zieminska E, Stafiej A, Lazarewicz J. Role of group I metabotropic glutamate receptors and NMDA receptors in homocysteine-evoked acute neurodegeneration of cultured cerebellar granule neurons. Neurochem Int 2003; 43, 481-92.

33. Meldrum BS. The role of glutamate in epilepsy and other CNS disorders. Neurology 1994; 44: 4-23.

34. Betzen C, White R, Zehendner CM, et al. Oxidative stress upregulates the NMDA receptor on cardiovascular endothelium. Free Radical Biol Med 2009; 47: 1212-20.

35. Zou CG, Zhao YS, Gao SY, et al. Homocysteine promotes proliferation and activation of microglia. Neurobiol Aging 2010; 31: 2069-79.

36. Folbergrova J. Anticonvulsant action of both NMDA and non-NMDA receptor antagonists against seizures induced by homocysteine in immature rats. Exp Neurol 1997; 145: 442-50.

37. Kubova H, Folbergova J, Mares P. Seizures induced by homocysteine in rats during ontogenesis. Epilepsia 1995, 36: 750-56.

38. Sener U, Zorlu Y, Karaguzel O, Ozdamar O, Coker I, Topbas M. Effects of common anti-epileptic drug monotherapy on serum levels of homocysteine, vitamin B12, folic acid and vitamin B6. Seizure 2006; 15: 79-85.

39. Stanojlovic O, Rasic-Markovic A, Hrncic D, et al. Two types of seizures in homocysteine thiolactone-treated adult rats, behavioral and electroencephalographic study. Cell Mol Neurobiol 2009; 29: 329-39.

40. Coenen AML, Van Luijtelaar, ELJM. Genetic animal models for absence epilepsy: a review of the WAG/Rij strain of rats. Behav Genet 2003; 33: 635-55.

41. Kostopoulos GK. Spike-and-wave discharges of absence seizures as a transformation of sleep spindles: the continuing development of a hypothesis. Clin Neurophysiol 2000; 111: S27-38.

42. Folbergrova J, Haugvicova R, Mares P. Seizures induced by homocysteinic acid in immature rats are prevented by group III metabotropic glutamate receptor agonist $(\mathrm{R}, \mathrm{S})$ 4-phosphonophenylglycine. Exp Neurol 2002; 180: 46-54.

43. Pinault D, Vergnes M, Marescaux C. Medium-voltage 5-9 $\mathrm{Hz}$ oscillations give rise to spike-and-wave discharges in a genetic model of absence epilepsy: in vivo dual extracellular recording of thalamic relay and reticular neurons. Neurosci 2001; 105: 181-201.

44. Sachdev PS. Homocysteine and brain atrophy. Prog Neuropsychopharmacol Biol Psychiatry 2005; 29:1152-1161.

45. Undas A, Perla J, Lacinski M, Trzeciak W, Kazmierski R, Jakubowski H. Autoantibodies against N-homocysteinylated proteins in humans: implications for atherosclerosis. Stroke 2004; 35: 1299-304.
46. Rasic-Markovic A, Stanojlovic O, Hrncic D, et al. The activity of erythrocyte and brain $\mathrm{Na}+/ \mathrm{K}+$ and $\mathrm{Mg} 2+-$ ATPases in rats subjected to acute homocysteine and homocysteine thiolactone administration. Mol Cell Biochem 2009; 327: 39-45.

47. Streck EL, Zugno AI, Tagliari B, Wannmacher C, Wajner $\mathrm{M}$, Wyse AT. Inhibition of $\mathrm{Na}+, \mathrm{K}+$-ATPase activity by the metabolites accumulating in homocystinuria. Metabol Brain Dis 2002; 17: 83-91.

48. Hrncic D, Rasic-Markovic A, Krstic D, Macut D, Djuric $\mathrm{D}$, Stanojlović $\mathrm{O}$. The role of nitric oxide in homocysteine thiolactone-induced seizures in adult rats. Cel Mol Neurobiol 2010; 30: 219-31

49. Van Leeuwen R, De Vries R, Dzoljic MR. 7-Nitro indazole, an inhibitor of

neuronal nitric oxide synthase, attenuates pilocarpine- induced seizures. Eur J Pharmacol 1995; 28:7211-7213

50. Kim JM, Lee H, Chang N. Hyperhomocysteinemia due to shortterm folate deprivation is related to electron microscopic changes in the rat brain. J Nutr 2002; 132: 3418-21.

51. Rauhala P, Khaldi A, Mohanakumar KP, Chiueh CC. Apparent role of hydroxyl radicals in oxidative brain injury induced by sodium nitroprusside. Free Radic Biol Med 1998; 24: 1065-73.

52. Hrncic D, Rasic-Markovic A, Djuric D, Susic V, Stanojlovic O. The role of nitric oxide in convulsions induced by lindane in rats. Food Chem Toxicol 2011; In press.

53. Rasic-Markovic A, Djuric D, Hrncic D, et al. High dose of ethanol decreases total spectral power density in seizures induced by D,L- homocysteine thiolactone in adult rats. Gen Physiol Biophys 2009; S28: 25-32.

54. Hillbom M, Pieninkeroinen I, Leone M. Seizures in alcohol-dependent patients: epidemiology, pathophysiology and management. CNS Drugs 2003; 17: 1013-30.

55. Wang $\mathrm{H}$, Jiang XH, Yang F, et al. Cyclin A transcriptional suppression is the major mechanism mediating homocysteine-induced endothelial cell growth inhibition. Blood 2002; 99: 939-45.

56. Simson PE, Criswell HE, Johnson KB, Hicks RE, Breese GR. Ethanol inhibits NMDA-evoked electrophysiological activity in vivo. J Pharmacol Exp Ther 1991; 257: 225-31.

57. Chandler LJ, Newsom H, Sumners C, Crews F. Chronic ethanol exposure potentiates NMDA excitotoxicity in cerebral cortical neurons. J Neurochem 1993; 60: 1578-81.

58. Rašić-Marković A, Hrnčić D, Djurić D, Macut D, Lončar-Stevanović $\mathrm{H}$, Stanojlović $\mathrm{O}$. The effect of Nmethyl-D-aspartate receptor antagonists on D,L-homocysteine thiolactone induced seizures in adult rats. Acta Physiologica Hungarica 2011: 98 (1), 17-26.

59. Petrovic M, Fufanovic I, Elezovic I, Colovic M, Krstic D, Jakovljevic V, Djuric D. The effect of homocysteine thiolactone on acetylcholinesterase activity in rat brain, blood and heart. Ser J Exp Clin Res 2010; 11 (1): 19-22. 


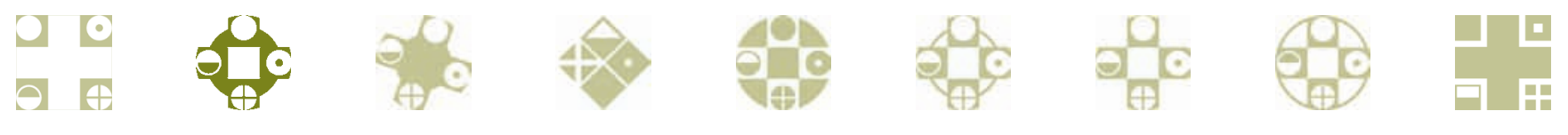

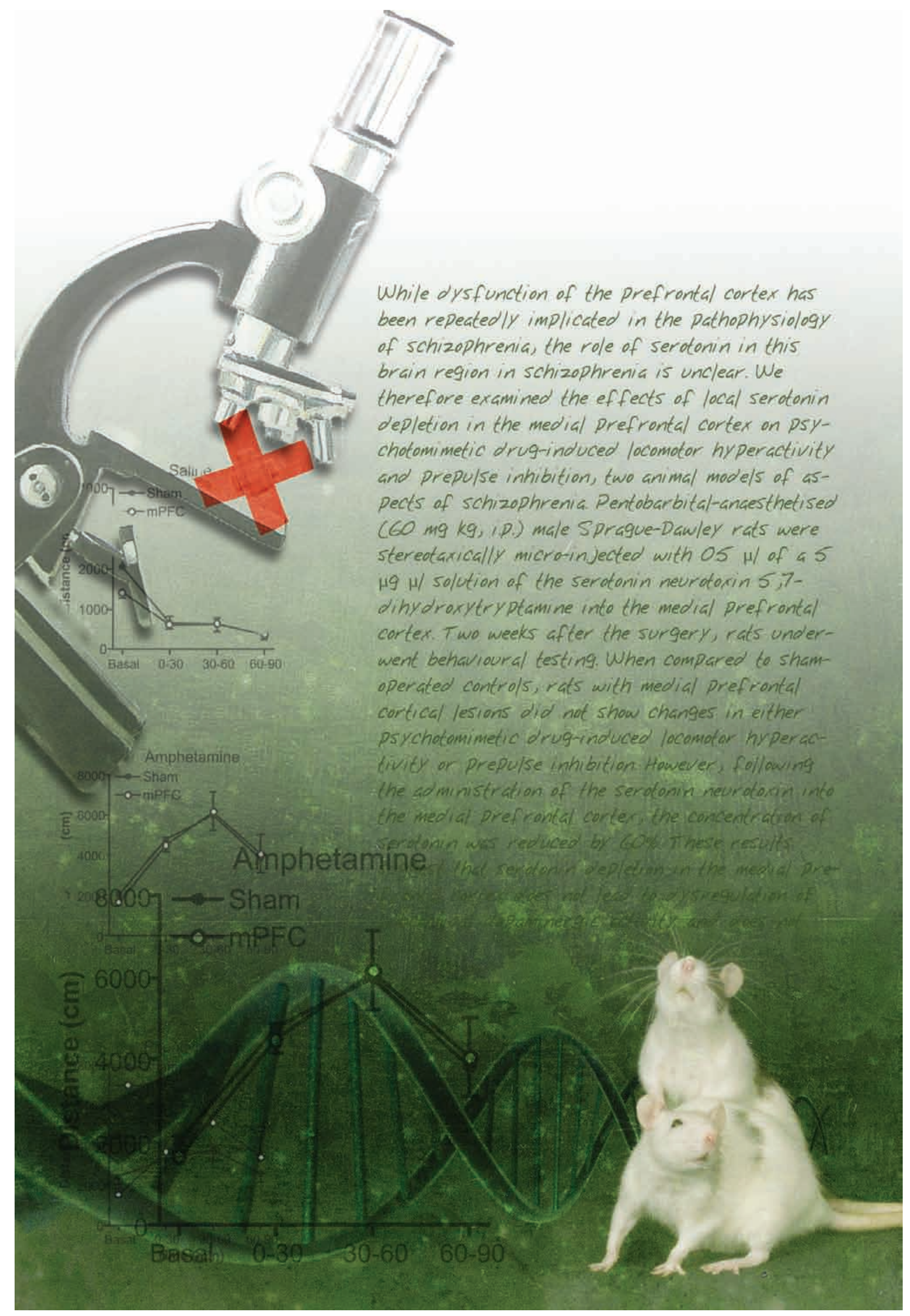

